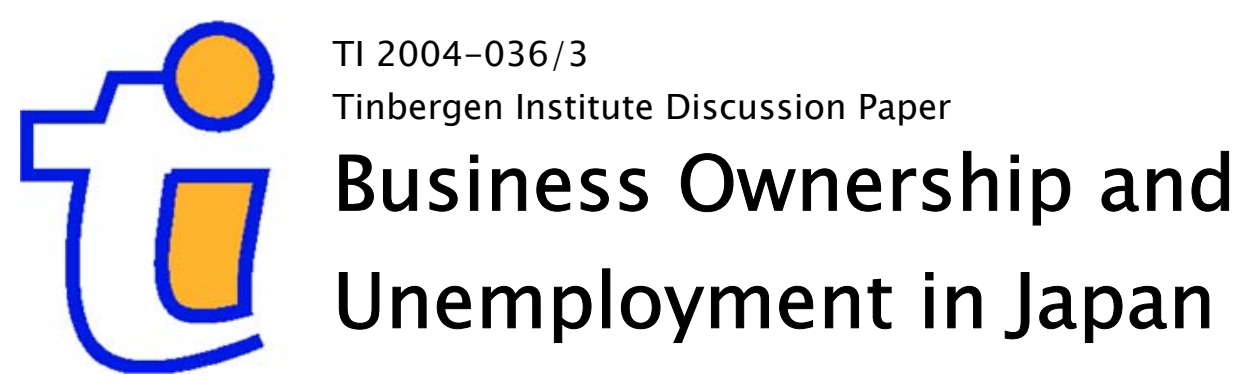

Joost van Acht
Joop Stam²
Roy Thurik ${ }^{2,3,4,5}$
Ingrid Verheu/2,4

1 Institute of Innovation Research, Hitotsubashi University, Tokyo, Japan,

2 Rotterdam School of Economics, Department of Economics, Erasmus Universiteit Rotterdam, The Netherlands,

3 Max Planck Institute, Jena, Germany,

${ }_{4}^{4}$ EIM Business and Policy Research, Zoetermeer, The Netherlands,

5 Tinbergen Institute. 


\section{Tinbergen Institute}

The Tinbergen Institute is the institute for economic research of the Erasmus Universiteit Rotterdam, Universiteit van Amsterdam, and Vrije Universiteit Amsterdam.

Tinbergen Institute Amsterdam

Roetersstraat 31

1018 WB Amsterdam

The Netherlands

Tel.: $\quad+31(0) 205513500$

Fax: $\quad+31(0) 205513555$

Tinbergen Institute Rotterdam

Burg. Oudlaan 50

3062 PA Rotterdam

The Netherlands

Tel.: $\quad+31(0) 104088900$

Fax: $\quad+31(0) 104089031$

Please send questions and/or remarks of nonscientific nature to driessen@tinbergen.nl.

Most TI discussion papers can be downloaded at http://www.tinbergen.nl. 


\title{
Business Ownership and Unemployment in Japan
}

\author{
Joost van Acht ${ }^{1}$, Joop Stam $^{2}$, Roy Thurik ${ }^{3,4}$, Ingrid Verheul ${ }^{3,4}$ \\ 1) Institute of Innovation Research \\ Hitotsubashi University, Faculty of Commerce \\ Naka 2-1, Kunitachi-shi, Tokyo, Japan \\ 2) Department of Modern Asian Studies \\ Rotterdam School of Economics, Erasmus University Rotterdam \\ P.O. Box 1738, 3000 DR Rotterdam, The Netherlands \\ 3) Centre for Advanced Small Business Economics \\ Rotterdam School of Economics, Erasmus University Rotterdam \\ P.O. Box 1738, 3000 DR Rotterdam, The Netherlands \\ and \\ Max Planck Institute, Jena, Germany \\ 4) EIM Business and Policy Research \\ P.O. Box 7001, 2701 AA Zoetermeer, The Netherlands
}

\begin{abstract}
The influence of industrial structure, more specifically of business ownership, is investigated on the level of unemployment in Japan. The question is to what extent business ownership, i.e., entrepreneurship, can reduce the level of unemployment. It will be concluded that Japan is hardly an outlier when using a simple model of the relationship between unemployment and the rate of business ownership. The model is calibrated using recent data of 23 OECD countries. It shows a minor underestimation of the rise in unemployment in Japan in the period 1984-2002. Arguments are brought forward why this might be the case. We argue that small firms in Japan have benefitted in the past from the protective environment of the keiretsu structure. In the current process of industrial restructuring, keiretsu support is dissipating, but has not yet been adequatly replaced with a market environment conducive to the establishment and growth of entrepreneurial firms. The underestimation of the rise in unemployment is a reflection of the limited access of small firms to the market in Japan.
\end{abstract}

Version: March 2004

JEL-code: E24 (employment, unemployment, wages), L16 (industrial organization and macroeconomics, macroeconomic industrial structure), L50 (regulation and industrial policy), M13 (entrepreneurship), O10 (economic development), O30 (technological change)

Keywords: entrepreneurship, business ownership, unemployment, economic growth, Japan

Acknowledgement: The authors would like to thank André van Stel for computational assistance and helpful comments. 


\section{Introduction}

Japan has historically had both a high degree of business ownership and low levels of unemployment. Moreover, a high share of the Japanese workforce is employed in small and medium sized businesses (SMEs). In 1999 these businesses accounted for 99.3 percent of all business establishments in Japan and 80.6 percent of employment (METI, 2002a). Since the beginning of the 1990s Japan entered a prolonged period of economic stagnation known as the lost decade during which Japan experienced very low to no growth. During this period business ownership levels declined drastically and within a decade unemployment levels more than doubled. These developments contrast a general trend towards a more entrepreneurial economy that can be observed in many other OECD countries. Amidst strong government efforts to revive the Japanese economy through increased entrepreneurship, many observers fear its economy is heading for a second decade of stagnating growth and increasing unemployment.

The economies of developed countries are in a transition from a state in which massproduction was the mainstay of business to an economy in which knowledge intensive activities form the cornerstone of economic activity. Audretsch and Thurik $(2001,2000)$ refer to this process as the transition from the managed to the entrepreneurial economy. In the managed economy technological trajectories were relatively well defined and hence firms were subject to relatively low uncertainty in planning their R\&D activities. Stability, continuity and homogeneity were the cornerstones of the managed economy (Audretsch and Thurik, 2001). Firms focused on the exploitation of scale economies and competed on operational efficiency. In the developed economies of the West, firms were confronted with high transaction costs leading to both horizontal and vertical integration. In the case of Europe and the U.S. the economic structure most conducive to growth favored the dominance of large firms and for three decades their economies experienced an increasing concentration of business.

Modern technology has lowered transaction costs and moved the advantage away from firms toward markets and the individual as the smallest possible firm (Audretsch and Thurik, 2001). Not only the advent of the knowledge economy contributed to this move (Audretsch and Thurik, 2000) but also that of modern organizational forms like networks and other loose alliances and relationships (Nooteboom, 1999; Castells, 1996, 1997, 1998). Changes in the direction of technological progress, along with changes in the world economy, resulted in a structural shift affecting the economies of all industrialized countries. Piore and Sable (1984) argue that the instability of markets in the 1970s resulted in the demise of mass production and promoted flexible specialization. This fundamental change in the path of technological development led to the occurrence of vast diseconomies of scale as a consequence of falling transaction costs. In other words it led to a new economy. Audretsch and Thurik (2000) refer to this economy as the entrepreneurial economy. Several studies have shown (Carree and Thurik, 2003) that entrepreneurship - and the effects it has on innovation, learning, competitive environment, the role of business owners, etc. - has a positive effect on economic growth. The capacity of an economy to renew itself through a process of creative destruction as had been advocated by Schumpeter is increasingly being considered crucial to economic progress in advanced economies.

Japan's experience in the post-war period contrasts with the developments in Europe and the United States. Confronted with an economy that had been devastated by World War II the Japanese started out with a considerable backlog in technological capability and know-how. However, they managed to catch up with their Western competitors in only a few decades and subsequently became a role model of economic development for other countries in the region. As a relative latecomer Japan was following a clear path of technological development that had been set out by its western competitors. Japan's competitiveness originated from its firms' ability to quickly absorb technological know-how imported from notably the U.S. and subsequently refining this technology and producing a wide variety of products. Japanese firms also managed to achieve 
superior levels of operational efficiency through the exploitation of scale economies (Porter, Takeuchi and Sakakibara, 2000).

The organizational approach of Japanese firms followed a different trajectory than that in Western firms. The trade-off for firms in the managed economy had always been the classic "make or buy decision", i.e. buy a product on the market or produce it within the firm when risks or transaction costs are high (Williamson, 1975). Western firms grew in size through vertical integration of the production hierarchy and horizontal mergers to exploit economies of scale. This led to increased concentration of business in the U.S. and Europe. The Japanese challenged this classic trade-off by employing alternative modes of production that relied on inter-corporate relations that allowed larger firms to cooperate closely with small firms without actually integrating them into the firm. This approach to production, which has become widely known as the keiretsu model, resulted in an industrial structure of several business conglomerates of large businesses floating atop a vast number of smaller subcontractors that supplied their parent firms with parts and intermediates. The nature of this relationship is hierarchical and small firms in these networks are no autonomous producers. Instead, keiretsu parent firms exercise control through a network of informal relations that enables them to maintain flexibility without losing control over the supply chain.

The turning point of the 1980s has had important consequences for Japan's competitive position. The superior operational efficiency of Japanese firms has slowly eroded as other countries in Asia expanded their production capacity and technological ability. Japanese firms responded to this global change by increasingly relocating their production to low cost countries. This development has been devastating for Japan's small business sector as many small firms suddenly saw their orders moving oversees to low-cost producers. Some firms have managed to make the transition to this new situation either by relocating their own production capacity overseas or by focusing on specialized or high tech products. However, a vast majority of the small business sector is struggling for survival and many firms have already ceased to exist. The Schumpeterian paradigm of creative destruction in Japan has led to a situation where the old subcontracting firms are faced with widespread destruction but where thus far the creation of new firms has not yet taken off (Cowling and Tomlinson, 2002).

In the present study we investigate the influence of industrial structure, more specifically of entrepreneurship, on the level of employment in Japan. The question is to what extent entrepreneurship (i.e., business ownership) can reduce the level of unemployment. In the present paper business ownership is used as a proxy for entrepreneurship. The terms entrepreneurship and business ownership are used as synonyms. In Section 2 we start our investigation with a brief discussion of the history of economic development in Japan and the restructuring process from the 1990s. In Section 3 we address the link between unemployment and business ownership and in

Section 4 we present our results. Section 5 focuses on the nature of business ownership and the economic environment in Japan and Section 6 concludes discussing some of the main findings, drawbacks and implications.

\section{Discussion of the industrial structure in Japan}

The performance of an industrial structure, measured in terms of economic growth, depends the degree to which the industrial structure utilizes scarce resources. The most efficient industrial structure does not alter in case its underlying determinants are stable. Chandler (1990), Scherer and Ross (1990) and Dosi (1988) conclude that a change in the underlying economic determinants will result in a change in the industrial structure most conducive to growth. The actual industrial structure of a country is determined by its specific cultural, institutional and economic background. Therefore, we can expect to encounter diversity among countries and find that some countries will be more successful than others in changing their economic structure to facilitate 
growth. The extraordinary economic performance of the Japanese economy in the 1950s and 1960s originated to a large extent from cultural and institutional aspects of the Japanese society. Attempts to implement elements of this model in other countries without a similar cultural and institutional background have therefore never achieved the same degree of success ${ }^{1}$.

To understand the relationship between unemployment and entrepreneurship in Japan (discussed in Section 3) it is important first to create insight into the characteristics and evolution of the industrial structure in Japan, and the role of small firms therein. In the present section we will provide a brief overview of the events that laid the foundation for Japan's industrial structure. Central in the discussion is the keiretsu structure, which has been influential in shaping the economic landscape in Japan.

\section{Keiretsu structure: dualism and 'quasi' firms}

The foundations of Japan's industrial structure were laid during the early stages of Japan's economic development in the Meiji era starting in 1868. The Meiji era saw Japan opening up to the rest of the world after nearly three centuries of seclusion. The sudden inflow of foreign ideas and technology marked the starting point of rapid growth and industrialization. Private entrepreneurship was an important mechanism for implementing foreign technology in production processes, although the Meiji government only provided assistance to a selected elite of established merchant entrepreneurs with close contacts to the government. Japan's smaller entrepreneurs were confronted with harsher conditions. They did not have direct access to foreign technology. This led small business owners to improve efficiency through continued experimentation with technologies that spilled over from the larger merchant entrepreneurs (Hirschmeier, 1964).

The growing power of the merchant entrepreneurs and the increasing scale of their operations, stimulated by the government, led to an oligopolistic economic structure in which large manufacturers pushed the small business sector in disadvantageous subcontracting relations. The growing differential in wages, prices and working conditions between large and small enterprises became known as the 'dual structure' of Japan's economy and was institutionalized in the zaibatsu model $^{2}$ (Whittaker, 1997). The keiretsu ${ }^{3}$ group structure, established after World War II, was largely based on the old zaibatsu but stood under strong influence of the government bureaucracy (Imai, 1980, Miyajima, 1994).

The keiretsu model created a dual industrial structure in Japan with several large powerful manufacturers at the centre of vertical keiretsu groups and a large number of smaller subcontractors. Moreover, they received preferential treatment in terms of access to scarce resources because the keiretsu were seen as the cornerstone of the economy by the government. Finally, the organization of the private sector with its hierarchical governance structure and strong ties between main banks and their keiretsu affiliates enabled large firms to pursue their own interests at the expense of their subcontractors (Cowling and Tomlinson, 2001). Hence,

\footnotetext{
${ }^{1}$ For cultural constraints inherent in the Japanese model, see for example Nakamura, Vertinsky and Zietsma (1997) on inter-firm cooperation, and Glisby and Holden (2003) on knowledge management.

${ }^{2}$ The end of World War II brought a short-lived reverse of this course when The Allied Command of the Occupational Forces ordered the dissolution of the pre-war zaibatsu conglomerates and favored an industrial policy in which small firms were to have a more prominent position. However, under threat of the growing power of the communist world these policies were soon abandoned.

${ }^{3}$ The term keiretsu (denoting 'link', connected to' or 'affiliated with') refers to a variety of Japanese inter-firm networks. Three types of networks can be distinguished. Horizontal keiretsu or kigyou shudan refer to corporate groups of large firms in non-related industries centered around a main bank. Vertical supplier keiretsu refer to a pyramid structure of firms, with a large firm at the top of a myriad of smaller subcontractors. The strong mutual commitment between suppliers and the large manufacturer at the core of the keiretsu enables close cooperation between members of one keiretsu group. Vertical distribution keiretsu can be identified as networks of complex distribution and retail channels (Lincoln, Gerlach and Ahmadjian, 1998).
} 
independent firms operating outside the sphere of the keiretsu groups did not receive government support and were confronted with limited access to the capital, labor and goods markets. ${ }^{4}$ The current process of restructuring is still hampered by the rigidity of these institutions that suited the keiretsu dominance.

Within the keiretsu structure the bipolar distinction between market and firm as mechanisms to allocate resources is substituted by 'quasi market' and 'quasi organizational' relations between firms (Imai and Itami, 1984). Large Japanese firms are part of horizontal keiretsu clusters centered around a main bank. These corporate groups or kigyo shudan played an important role in the allocation of financial resources. The main banks were conducive to solving problems of information asymmetry and contributed to long-term and low-cost financial stability. Moreover, the vertical keiretsu structure induces inter-firm transactions between subcontractors and parent firms that transcend simple market transactions. There is a long-term commitment between both parties, including the exchange of employees, sharing of knowledge and technology and a stable flow of orders. While formally not under the control of the parent firm, subcontracting firms are subordinate to the strategic decision making at the top of the supply chain (Cowling and Tomlinson, 2002). Parent firms provide informal guidance to their suppliers with respect to production planning and technology development. Employees and entrepreneurs of these small subcontracting firms have strong commitment and association towards their parent firm. It is in this context that Japan's small firms have been referred to as 'quasi' firms, indicating their limited independence from the larger keiretsu groups ${ }^{5}$.

\section{Changes in economic structure}

The keiretsu production model reached its height in the 1970s when changing economic circumstances forced Japanese firms to carry out drastic rationalization. Production practices such as total quality control (kaizen) and just-in-time production (kanban) were adopted enabling Japanese firms to achieve superior levels of operational efficiency ${ }^{6}$. The 1970 s were in many respects a turning point for the success of the keiretsu model. The impact of the dollar crisis in 1971, and more manifestly the 1973 oil crisis, revealed Japan's strong dependence on imported energy and vulnerability to volatile markets. Firms responded by expanding into more knowledge intensive industries that would reduce dependence on energy sources. The superior efficiency of the keiretsu model still proved successful throughout the 1970 s demonstrated by the global dominance that was achieved by Japanese firms in the electronics and machine tool industry. However, firms were slowly experiencing the impact of the knowledge economy on their competitiveness but failed to take adequate steps to adapt to this new environment.

The intense rationalization and upgrading of technological capabilities among small firms that had taken place in the 1970s had narrowed the gap between small and large enterprises and in the early 1980 s many small firms had reached virtually equal technological sophistication. For

\footnotetext{
${ }^{4}$ Critics of the dual structure thesis have argued that the real economic structure was much more pluralistic than the dual structure theorists had put forward. Nakamura, one of the most outspoken critics during the 1970s, already envisioned that the knowledge economy would lead to a breakdown of existing economic structures and pointed to the existence of leading medium sized firms or chuken kigyo that would take over the role of the large keiretsu firms. See Nakamura et al. (1981) as quoted by Whittaker (1997). Indeed, though operating under difficult conditions, a large proportion of Japan's small business sector was already operating as independent producers and did not engage in subcontracting.

${ }^{5}$ Still, the mutual interdependence between firms was beneficial to both parties. The longstanding relations between subcontractors and producers enabled firms to cooperate in developing new technology without sacrificing flexibility. Also, competition between subcontractors guaranteed low-cost production. Subcontractor firms benefited from the keiretsu framework because of the supply of low-interest capital through the keiretsu banks, credit guarantees provided by parent firms, access to advanced technology and know-how and a stable flow of orders.

${ }^{6}$ Kaizen and kanban are elements of a generalized model of the Japanese firm that gained ground in the 1970s and 1980s. In reality however, the Japanese firm has been the product of an evolution and firms have always adapted to new circumstances. Aoki (1990) provides an overview of the many aspects of Japanese firms.
} 
some entrepreneurs this led to a more independent existence and during the 1980 s subcontracting rates slowly started to decrease (METI, 2003, p. 28). The steady growth of the economy put pressure on the labor market and for small firms it became increasingly difficult to attract qualified personnel. Also, it became clear that there would be limits to efficiency improvements. The 1990s also unveiled the fact that economic growth in Japan had always been facilitated by the backlog in technological capabilities, enabling progress through a process of catching-up. However, since the 1970s Japanese firms had gradually improved their technological knowledge and capability and turned from followers into leaders in several industries (Gerlach and Lincoln, 2000).

Overconfidence in the Japanese economy and an expansionary monetary policy led to an economic bubble of skyrocketing land and asset prices in the late 1980s. The collapse of the bubble economy in the 1990s led to a crisis in the financial sector, which would also affect other sectors and turn the economy into a recession. By the 1990s the Japanese economy was characterized by low to no growth, high debts, sluggish demand followed by deflation in the late 1990s. At the same time there was a growing awareness of the fact that competitors in the Asian region had been building up their productive capacity and upgraded their technological capabilities. Japanese firms had fuelled this competition by channeling FDI flows to countries in this region. For Japan's small subcontractors this competition presented an important threat. Small firms that had depended on their keiretsu parent firm for decades suddenly saw their orders move overseas. Unable to compete on price with the new Asian competition and lacking experience in presenting themselves in the market, many of these firms went bankrupt or were forced to close ${ }^{7}$ (Ikeda, 1998).

The 1990s are often referred to as Japan's lost decade. However, the loss of confidence in the Japanese model and the struggle of both large and small businesses led to changes in industry that had been considered impossible before the burst of the bubble economy. For instance, the bad financial health of the city banks led to a wave of mergers between main banks of different keiretsu groups. These mergers watered down the strong segregation between corporate groups and created opportunities for firms in the keiretsu hierarchy to widen the scope of their business. Moreover, cross shareholding within the keiretsu groups, which had always been a protective measure against hostile takeovers and the influence of stockholders, diminished (Inoue, 2000). The case of Nissan Corporation, taken over by Renault in 1999, demonstrates the impact of this development. The new management of Nissan closed down production facilities and drastically reorganized Nissan's subcontracting structure. The radically different approach to corporate restructuring and lack of 'Japanese social considerations' sent shockwaves through Japan's business community (Larimer, 2003).

From 1999 onwards, a series of reforms has been implemented to stimulate new venture creation and promote the innovativeness of small firms in Japan (METI, 2002b). An important element of these reforms is the strengthening of mechanisms for technology transfer between knowledge institutions (e.g., universities) and the small business sector to stimulate innovation. Furthermore, the Japanese government aims at promoting the formation of regional clusters and other cooperative alliances between firms. In 2002 and 2003 the Japanese economy shows signs of recovery. At present it is too early to assess whether this recovery is attributable to the institutional changes (mentioned above) and it is not clear if this 'revival' will be persistent in the near future.

\section{Linking entrepreneurship and unemployment}

The 1980s were a turning point with many facets and consequences. Audretsch and Thurik (2001) contrast the most fundamental elements of the managed economy model with those of the entrepreneurial economy model and identify fourteen dimensions as the basis for comparing

\footnotetext{
${ }^{7}$ The term kudoka or 'hollowing out' refers to the rapid weeding out of Japan's small business sector.
} 
models of the entrepreneurial and the managed economy. ${ }^{8}$ In addition, there are both conceptual and empirical indications that entrepreneurship enhances growth (Carree and Thurik, 2003). The quintessential question now is whether, at the end of the day, the entrepreneurial economy leads to less unemployment than the managed one. In other words: the question is whether a rise in entrepreneurship leads to lower levels of unemployment.

The relationship between unemployment and entrepreneurship has been shrouded with ambiguity. The theory of income choice has been the basis for numerous studies focusing on the decision of individuals to start a firm and become an entrepreneur. This theory suggests that increased unemployment will lead to an increase in start-up activity on the grounds that the opportunity cost of not starting a firm has decreased. However, there is an important counterargument in that the unemployed tend to possess lower endowments of human capital and entrepreneurial talent required to start and sustain a new firm, suggesting that high unemployment may be associated with a low degree of entrepreneurial activity. A low rate of business start-ups may also be a consequence of low economic growth levels, which correlate with higher levels of unemployment. Entrepreneurial opportunities are not just the result of the push effect of (the threat of) unemployment but also of the pull effect produced by a thriving economy as well as by entrepreneurial activities in the past. In addition to unemployment leading to more or less start-up activity, the reverse has also been claimed to hold. New-firm start-ups hire employees, resulting in subsequent decreases in unemployment. But there is a counterargument. The low rates of survival combined with the limited growth of the majority of small firms imply that the employment contribution of start-ups is limited at best, which would argue against entrepreneurial activities reducing unemployment (Audretsch, Carree and Thurik, 2001).

The ambiguities found in the empirical evidence reflect these two conflicting forces. It is generally assumed that there is a two-way causation between changes in the level of entrepreneurship and that of unemployment: a "Schumpeter" effect of entrepreneurship reducing unemployment and a "refugee" or "shopkeeper" effect of unemployment stimulating entrepreneurship. Audretsch, Carree and Thurik (2001) try to reconcile the ambiguities found in the relationship between unemployment and entrepreneurship. They present a two-equation model where changes in unemployment and in the number of business owners are linked to subsequent changes in those variables. Their model is based on a framework using elements of the Gibrat's Law literature. Their empirical results are based upon the COMPENDIA (COMParative ENtrepreneurship Data for International Analysis) dataset constructed by EIM Business and Policy Research, Zoetermeer. See EIM (2003). They use version 2000.1 containing data of 23 OECD countries over the period 1974 through 1998. The COMPENDIA data also form the basis for the analysis and discussion in the subsequent section. We use version 2002.1. This dataset includes (un)employment figures for the period 1970-2002 and business ownership figures for the period 1972-2002 for 23 OECD countries.

In Audretsch, Carree and Thurik (2001) the existence of two separate relationships between unemployment and entrepreneurship (i.e., business ownership) is identified including significant "Schumpeter" and "refugee" effects. For the purpose of the present paper focusing on the case of Japan we deal with the "Schumpeter" side of the relationship. ${ }^{9}$ To test this first hypothesis that an increase in entrepreneurial activity leads to a decrease in subsequent unemployment Audretsch, Carree and Thurik (2001) estimate the following equation:

$$
U_{t}-U_{t-L}=a+b\left(E_{t-L}-E_{t-2 L}\right)+c\left(U_{t-L}-U_{t-2 L}\right)+e_{t},
$$

where $U$ is the unemployment rate (unemployed per work force), $E$ is the self-employment rate (business owners per work force) and $e$ is a random coefficient. The index $t$ refers to the year

\footnotetext{
${ }^{8}$ See Audretsch and Thurik (2004) for an updated version.

${ }^{9}$ Similarly, COMPENDIA (version 2000.2) is the basis of an analysis investigating the influence of entrepreneurship on unemployment in the United Kingdom and Spain, respectively. See Thurik (2003) and Thurik and Verheul (2003).
} 
and $L$ to the time lag. The expected sign of the coefficient $b$ is negative. The lagged endogenous variable is used on the right hand side to "correct" for reversed causality. ${ }^{10}$

Audretsch, Carree and Thurik (2001) estimate equation (1) using the panel data set consisting of 23 OECD countries in the period 1974 through 1998 (COMPENDIA version 2000.1). Weighted least squares using the number of self-employed is applied. They report values of the coefficients $a, b$ and $c$ of 0.004 (1.0), - 0.78 (2.6) and -0.18 (2.1), respectively, with absolute $\mathrm{t}$-values between parentheses, given that a time lag is used of eight years, $L=8^{11}$. Using an eightyear time lag 46 data points are available. The relatively long lag structure of eight years is justified because the employment impact of entrepreneurship is not instantaneous. Rather, it requires a number of years for the firm to grow. ${ }^{12}$ Coefficient $b$ is less than zero and significant. This implies that there exists a clear "Schumpeter" effect of entrepreneurship (i.e., business ownership) reducing unemployment. The negative effect of lagged unemployment on subsequent unemployment, $c<0$, is probably an indicator of cyclical effects related to the influence of policy measures. The autonomous change in the unemployment level, $a$, does not differ from zero. For the present case we use the new, extended data set of the 1972-2002 period (COMPENDIA version 2002.1). Here a six year lag proves to have the best results. Using a six year lag 92 data points are available. Using equation (1) the coefficients $a, b$ and $c$ show values of 0.01 (3.3), -0.88 (3.4) and -0.36 (3.5), respectively, with absolute t-values between parentheses. As opposed to the results using the earlier data set we now observe a small positive autonomous effect.

The small business sector, and hence business ownership, is generally assumed to be of considerable importance in modern OECD economies. The present exercise shows the importance of its role bringing down unemployment. Similar results are shown in earlier studies (White, 1982; Audretsch, 1995; Kwoka and White, 2001; Carree and Thurik, 2003). In the next section we will present some computations as to how this works out in Japan.

\section{Unemployment and entrepreneurship in Japan}

In the present section we will discuss developments in unemployment and entrepreneurship (i.e., share of business owners in the labor force) in Japan in the period between 1970 and 2002. Finally, we will discuss some results when applying equation (1) to Japan.

\section{Developments in unemployment}

Figure 1 presents the development of unemployment in the period between 1970 and 2002 for Japan and four other OECD countries: France, Germany, The Netherlands and the United States. These four countries are chosen as a benchmark because the development of entrepreneurship and its determinants in these countries is discussed extensively in Audretsch, Thurik, Verheul and Wennekers (2002). Generally, the unemployment level in Japan in the period between 1980 and 1998 has been considerably lower than that in the other countries. Only from the end of the 1990s onwards the Japanese unemployment level reached that of other OECD

\footnotetext{
${ }^{10}$ The Granger (1969) approach to the question of whether $\mathrm{x}$ causes $\mathrm{y}$ is to see how much of the current $\mathrm{y}$ can be explained by past values of $y$ and then to see whether adding lagged values of $x$ can improve the explanation. $y$ is said to be Granger-caused by $\mathrm{x}$ if $\mathrm{x}$ helps in the prediction of $\mathrm{y}$, or equivalently if the coefficients on the lagged $\mathrm{x}$ 's are statistically significant. Two-way causation is frequently the case; $\mathrm{x}$ Granger causes y and y Granger causes x. It is important to note that the statement " $x$ Granger causes $y$ " does not imply that $y$ is the effect or the result of $x$. Granger causality measures precedence and information content but does not by itself indicate causality in the more common use of the term.

${ }^{11}$ See Audretsch, Carree and Thurik (2001) for results using a time lag of 4 and 12 years.

12 In this respect Geroski (1995, p.148) argues that: "Even successful entrants may take more than a decade to achieve a size comparable to the average incumbent". Audretsch (1995) shows that the share of total employment accounted for by a cohort of new ventures in United States manufacturing more than doubles for firms between two and six years old (no evidence was provided beyond six years).
} 
countries. The development of unemployment in Japan between 1970 and 2002 is characterized by less variation as compared to the other four countries. It increased from one percent in 1970 to two percent in 1990, and subsequently to 5.5 percent in 2002. The pronounced cyclical pattern of unemployment in most Western countries shows vehement increases in the early 1980s and early 1990s. These increases can also be observed in the Japanese case, although to a lesser extent.

Figure 1: Unemployment (\% of workforce) in the period 1970-2002

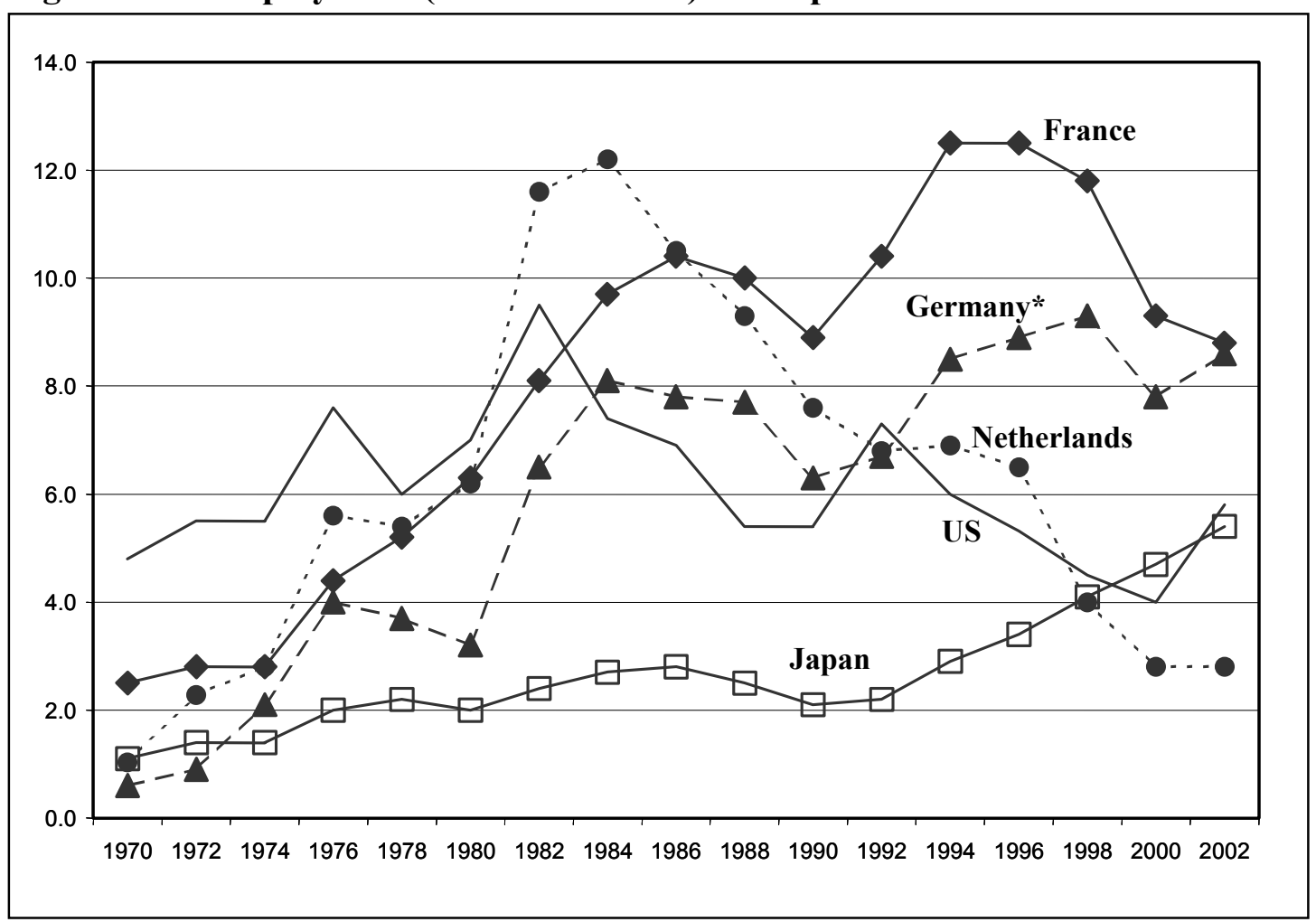

Source: EIM COMParative ENtrepreneurship Data for International Analysis (COMPENDIA 2002.1) ${ }^{13}$

* The data for Germany refer to West Germany for the period 1970-1990.

Japan's economic system has always been admired for sustaining very low levels of unemployment even in times of economic downturns. These sustained low levels of unemployment throughout its economic development can be partially attributed to the high growth rate of this period, but also the specific nature of the Japanese employment system contributed greatly to low unemployment. The characteristics of this system such as long-term job security, limited ports of entry and seniority wages resulted in reliance on internal employment adjustment as a mechanism to cope with changes in demand and technology ${ }^{14}$.

The keiretsu conglomerates and their associated firms have played an important role in employment adjustment in past recessions. In times of economic adversity, such as the oil crises of the 1970s, troubled keiretsu firms would redeploy their employees by sending them to subsidiaries or related firms in other sectors. The rise in energy prices during the oil crisis hit particularly hard on the manufacturing sector. The response of manufacturing firms was to send their employees to associated keiretsu firms in other sectors such as retailing, construction and services. The shock absorbing effect of these sectors prevented widespread lay-offs by manufacturing firms (Chuma, 2002a). In contrast to earlier recessions, the Heisei recession of the 1990s has led to an increase in unemployment. Keiretsu ties between firms have weakened considerably since the 1980s, making

\footnotetext{
${ }^{13}$ For details on the COMPENDIA data collection, we refer to Van Stel (2003).

${ }^{14}$ These practices mainly characterize large firms. Employment practices in smaller firms are more dynamic and labor mobility is much higher.
} 
it difficult to call on subsidiaries to accept redundant personnel. Moreover, the Heisei recession has had a broader impact across sectors than the two oil crises of the $1970 \mathrm{~s}^{15}$.

During the 1990s small firms were not a major source of personnel reductions; they even contributed to employment creation. Employment in the small business sector only started to decline after 1997 when the Heisei recession deepened and the number of business closures increased sharply ${ }^{16}$. Personnel reductions mainly occurred in large firms implementing substantial cutbacks in employment from the beginning of the 1990s. However, although lifetime employment and the seniority wage system are said to be dissipating, it appears that job tenures in large firms increased during most of the 1990s (Genda and Rebick, 2000). Personnel reductions in large firms have mainly taken place through reducing new hires and the number of older employees through redeployment to affiliate firms and involuntary separations ${ }^{17}$. Because employment adjustment has mainly taken place within (large) firms, alternative adjustment mechanisms, such as adjustment through the labor market, are not well developed. With unemployment rising from the 1990s onwards due to restructuring of the keiretsu firms and a strong rise in bankruptcies, these market mechanisms are increasingly important.

Although from the 1980s onwards employment policy in Japan emphasized skill development of employees, experience with effective job placement and (re)training of personnel to remedy 'mismatch unemployment' is still limited (Kameyama, 2001). In addition, the relative underdevelopment of a secondary labor market is an obstacle to employment adjustments. At the same time, technological change has created a need for a flexible labor market for employees with specialized skills. However, the transfer of employees between firms has not been a common practice in Japan and in many firms efficient recruitment systems are lacking. During the 1990s these practices have been changing gradually ${ }^{18}$, but many firms still tend to redistribute employees between keiretsu group firms as a means of employment adjustment, reflecting the strong reliance on the organization as opposed to the market mechanism to allocate (human) resources (Chuma, 2002b, Kato, 2001).

In short, unemployment levels in Japan have shown a steady increase during the 1980s and accelerated during the $1990 \mathrm{~s}^{19}$. However, employment levels have risen in the $1980 \mathrm{~s}$ and $1990 \mathrm{~s}$, largely due to the increased labor participation of women since the 1980s (resulting in a more than proportional increase of female employment levels $)^{20}$.

\section{Developments in entrepreneurship}

The development of the business ownership in France, Germany, the Netherlands, Japan and the United States is depicted in Figure 2. ${ }^{21}$ The pattern of development in Japan differs from that of the other countries: it is consistently higher until the mid 1990s. From Table 1 we see that there

\footnotetext{
${ }^{15}$ The service sector and the construction sector experienced a slow-down in growth during the 1990s and firms in these sectors could no longer absorb excess labor from their affiliates in other sectors (Chuma, 2002).

${ }^{16}$ The economic situation of the small business sector was aggravated by the effects of deregulation measures, the entrance of foreign competitors into 'secure' markets, and the transfer of industrial activities abroad through FDI.

${ }^{17}$ The result of these employment adjustment methods is that the composition of the unemployed is roughly composed of redundant older employees and inexperienced young graduates.

${ }^{18}$ Indeed, Genda (1998) finds that in the period between 1991 and 1995 job creation decreased and job destruction increased.

19 According to Abe and Ohta (2001) the segmentation of the Japanese labor market (by industry) has had an important contribution to worsening of unemployment in Japan.

${ }^{20}$ The female share in the Japanese labor force in 2001 amounted up to 40.9 percent (source: Global Entrepreneurship Monitor data). Low unemployment levels in the past were partly related to the strong "discouraged worker" effect among women, who would withdraw from the labor market on becoming unemployed.

${ }^{21}$ It involves non-agricultural entrepreneurship, including the owners of both incorporated and unincorporated businesses, but excluding so-called unpaid family workers and wage-and-salary workers operating a side-business as a secondary work activity. See EIM (2003).
} 
are two large countries with a serious drop in the business ownership rate in the period 1986-2000: Japan and France. The development of entrepreneurship in several OECD-countries can be characterized by a U-shaped trend, with a decrease in entrepreneurship till the mid-eighties and an increase afterwards (Carree, Van Stel, Thurik and Wennekers, 2002; Audretsch, Thurik, Verheul and Wennekers, 2002). At first sight the developments in the United States, Japan and France are not in conformity with this U-shaped pattern. However, although not visible in Figure 2, the share of entrepreneurs in the United States declined until the early 1970s (Blau, 1987; Gartner and Shane, 1995) and increased from the early 1970s onwards. With respect to the developments in France there is some speculation that entrepreneurship in France will increase in the near future, showing the U-shaped development, albeit one that is initiated at a later point in time ${ }^{22}$. Hence, whereas entrepreneurship in most OECD countries shows a U-shaped development, the year of the turning point differs between countries. What appears to be a divergence is, in fact, a process of convergence (Audretsch, Thurik, Verheul and Wennekers, 2002). The reversal of the downward to an upward trend marks the transformation from the managed to the entrepreneurial economy (Audretsch and Thurik, 2000 and 2001). As yet, in Japan there is no sign of this reversal.

\footnotetext{
${ }^{22}$ This prediction is justified by the fact that hindering factors, such as the interlock of government, regulations and the large firm domination, are being reduced, thereby paving the way for entrepreneurship (Henriquez, Verheul, Van der Geest and Bischoff, 2002).
} 
Figure 2: Business owners (as share of workforce) in the period 1972-2002

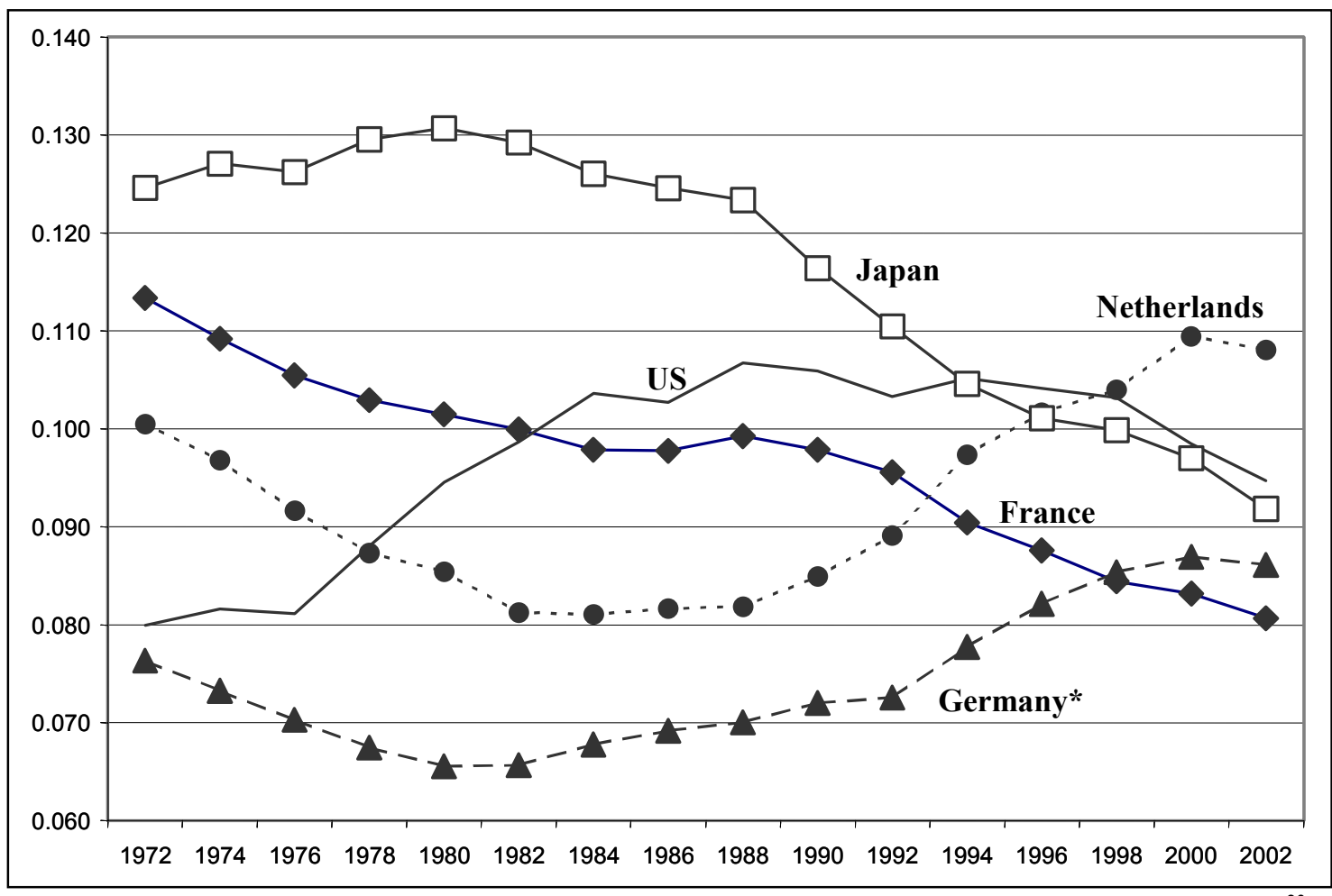

Source: EIM COMParative ENtrepreneurship Data for International Analysis (COMPENDIA 2002.1) ${ }^{23}$

* The data for Germany refer to West Germany for the period 1972-1990.

Table 1 presents the business ownership rates for the 23 OECD countries of which data are used for estimating equation (1). It enables to compare entrepreneurship in Japan with more countries than the four mentioned above. It is striking to see that, in comparison with the other OECD countries, the Mediterranean countries, including Greece, Portugal, Italy and Spain, have a high level of entrepreneurship throughout the period between 1972 and 2002. These high levels of entrepreneurship do not necessarily imply that their contribution to employment and GDP is high since we have not corrected for the innovativeness of the entrepreneurs, i.e., we have made no distinction between "Schumpeterian" entrepreneurs and "shopkeepers" or "refugee" entrepreneurs. It is likely that entrepreneurs in the Mediterranean countries have different characteristics than entrepreneurs in, for instance, the Scandinavian countries. Moreover, the Mediterranean countries have a relatively low per capita income, accompanied by a more traditional industrial structure and different cultural settings. For instance, their populations show relatively high degrees of dissatisfaction (Wennekers and Thurik, 2001; Wennekers, Thurik, Noorderhaven and Hofstede, 2002). Other countries with a high level of business ownership are Canada, Australia and New Zealand, where Canada in particular shows a remarkable growth of almost five percent points in the entire period. There are only four countries with a more than one percent point decline in the 1986-2002 period: Norway, France, Luxembourg and Japan. Japan shows the highest decline of these four countries.

${ }^{23}$ For details on the COMPENDIA data collection, we refer to Van Stel (2003). 
Table 1: Business owners as a percentage of the labor force in 23 OECD countries

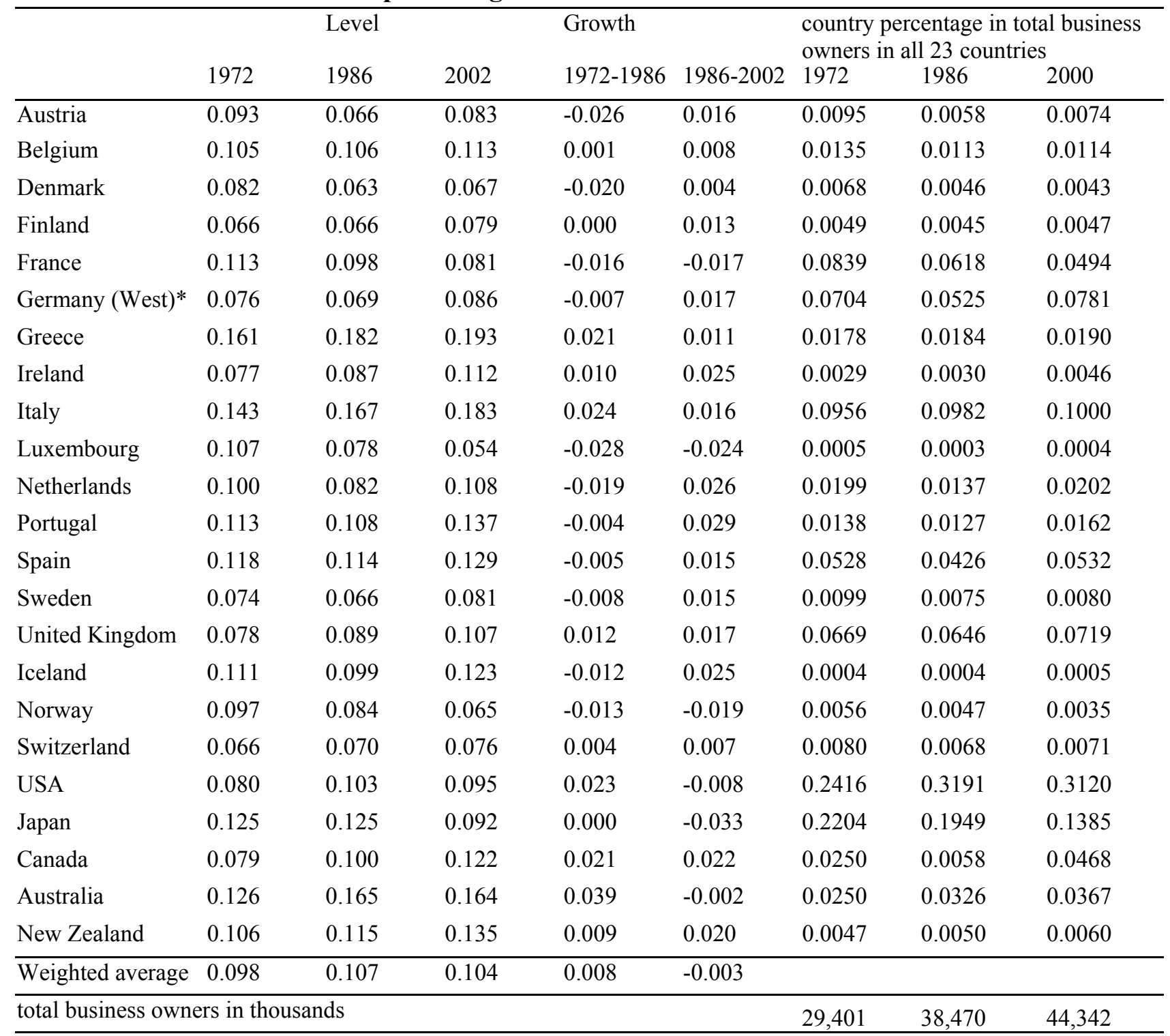

* The data for Germany refer to West Germany for 1972 and 1986.

Source: EIM (2003): COMParative Entrepreneurship Data for International Analysis (COMPENDIA 2000.2)

From Table 1 we observe that, contrary to the developments in most OECD countries, entrepreneurship in Japan decreases. While Japan historically had a very high share of business owners up to the 1970s, the succeeding decades show a steady decline in business ownership. This decline can be attributed to an increase of business closures and a decline of new firms or startups. Figure 3 documents the start-up (entry) and closure (exit) rates of firms in Japan. 


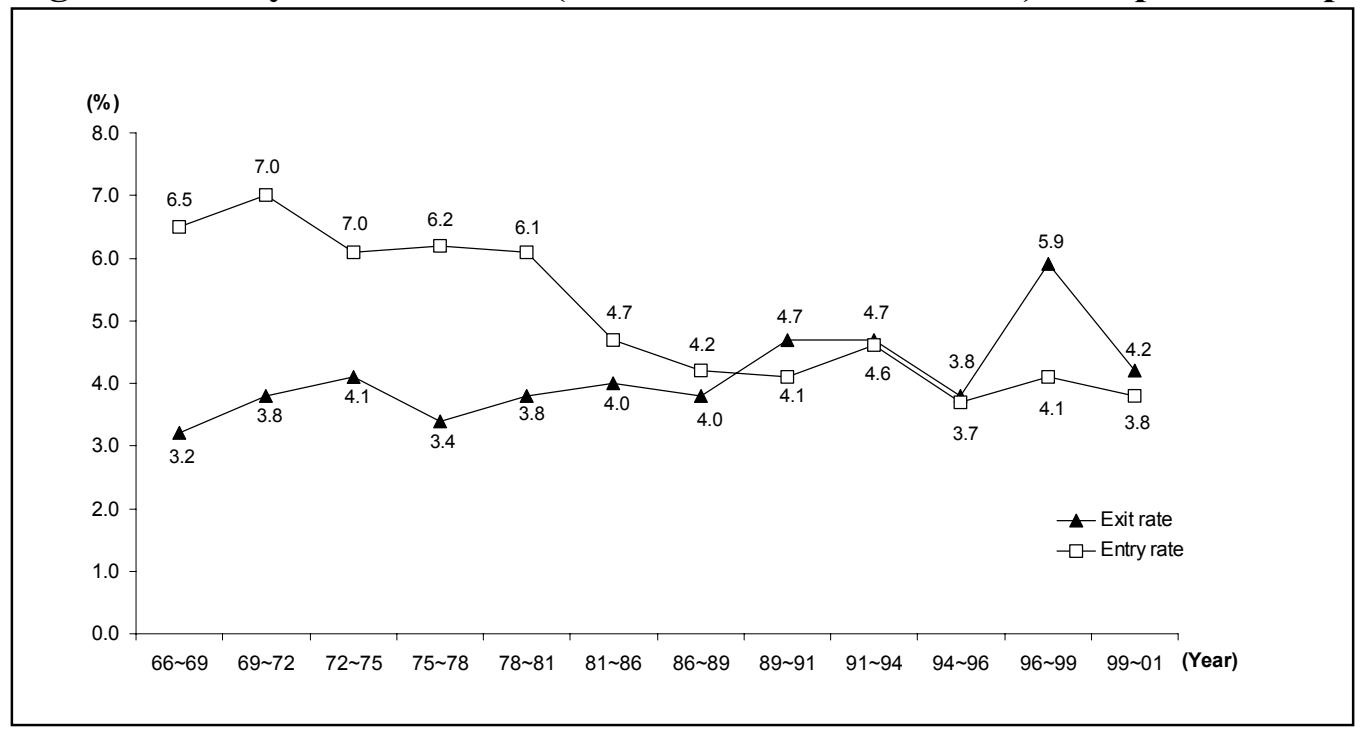

Source: METI (2003), White Paper on Small Medium Enterprises 2003.

From Figure 3 we see that the number of business failures is relatively stable throughout the 1970 s and 1980s at three to four percent. The economic recession in the early 1990s led to an increase in bankruptcies, followed by a modest recovery in the mid-1990s. From 1997 the exit rate increased again and peaked at 5.9 percent in the period between 1996 and 1999, the highest level of business closures in decades. More recent figures show that the number of closures is again declining. Conversely, start-up activity has steadily decreased since the 1970s when the Japanese economy was still experiencing high growth. A detailed analysis of firm entry statistics in the White Paper on small and medium sized enterprises (METI, 2002a) suggests a structural decline of the start-up rate since the collapse of the bubble economy. Combining the developments in entry and exit rates, we observe that until the end of the 1980s the start-up rate exceeded the business closure rate, leading to an increase in business ownership. The early 1990s marked a turning point and the number business closures now exceeds the number of start-ups. Hence, from the 1990s onwards business ownership shows a downward trend (see Figure 2).

How can we explain these twin developments of an increase in business closures and a decreasing start-up rate? We argue that both developments ensue from a slow restructuring process of the keiretsu production model.

The business environment in Japan has changed considerably since the 1960s and 1970s when the keiretsu structure was still the central modus operandi of Japanese business. The keiretsu structure was not only a production modus beneficial to large firms, small firms also benefited from this system through the support they received from their parent firms such as financial support through the main bank, assistance in developing new technology and long-term stability in terms of a steady flow of orders. Risks were reduced through the stability and benefits of the subcontracting relation. Hence, the keiretsu system had a mitigating effect on the risks borne by individual entrepreneurs within the keiretsu group, making it easier for risk-averse individuals to start a firm. Kawai and Urata (2002) find that subcontracting opportunities have a positive effect on small firm entry. With the restructuring of Japan's industry and the less prominent role of the keiretsu firms the safe haven for small firms disappeared. It has however not yet been adequately replaced with an alternative institutional structure stimulating new venture creation. The impact of these changes can be illustrated by some of the most cited problems that start-up firms encounter, including problems acquiring financial capital, entering the market as newcomers because of the 
existence of so-called 'business channels' of established firms, and finding skilled personnel, presented in the SME White Paper 2002 (METI, 2002a).

The increasing closure rate is also related to the restructuring process. Small subcontracted firms in the manufacturing sector have long enjoyed a protective environment within the keiretsu framework. Competition was usually limited to Japanese competitors with comparable cost structures. Since the 1980s foreign competition has intensified with an expansion of low-cost production facilities and increased technological capabilities of East-Asian competitors. To remain globally competitive, large firms saw no choice but to venture abroad. In the 1990s large keiretsu firms also began to struggle and tried to increase profitability by pressing suppliers or outsourcing to low-cost facilities abroad (Cowling and Tomlinson, 2002). The effect of intense foreign competition, the weakening keiretsu ties, and the complete lack of experience of small firms to present themselves on the market resulted in a high rise in business closures ${ }^{24}$. Although many small (inefficient) firms are not able to survive under the harsh market conditions, other firms adjusted to the new situation by moving their production facilities to low-cost locations in Asia ${ }^{25}$, upgrading their technological capability and pursued a strategy of independence through specialization and market diversification (Whittaker, 2002).

The protective environment of the keiretsu framework has been weakened ever since the 1980s, making entrepreneurs increasingly dependent on the market. Although in the last two decades the importance of small firms as a source of economic growth is increasingly acknowledged and new firm creation has become a national priority ${ }^{26}$, large businesses still exercise strong control over key areas of the economy which stands in the way of transition to a market economy that is more open to the small business sector ${ }^{27}$. Already in the 1970s there was criticism of the keiretsu model. However, the success of this same model had stood in the way of transition. With the Heisei recession and perhaps more profoundly with the deepening of the recession in 1997 the need for change is more eminent than ever. It is therefore disconcerting to see that the growing importance attributed to small firms has been paired with a decrease rather than an increase in the number of business owners in Japan.

\section{The relationship between unemployment and entrepreneurship}

To determine whether and to what extent the contribution of entrepreneurship (i.e., business ownership) to reducing unemployment in Japan deviates from that in other countries we make use of equation (1) using $L=6$ where coefficients $a, b$ and $c$ are $0.01,-0.88$ and -0.36 , respectively. It is straightforward to calculate the estimated values of the residuals $e_{t}$ for Japan for $t=1984,1990$, 1996 and 2002: they are 1.2, -0.7, 0.2 and 1.1 percent, respectively. In other words: the model represented by equation (1) fits rather well for the Japanese case with a minor tendency for underestimation. This minor underestimation of unemployment could be explained by the fact that the nature of business ownership differs from that in other countries or that the economic and/or

\footnotetext{
${ }^{24}$ While other advanced economies are facing similar competition, the fact that Japan has a relative strong concentration of small businesses in medium-tech manufacturing industries that are vulnerable to the new competition in East Asia explains why the process of 'hollowing out' has such a deep impact in the case of Japan.

${ }^{25}$ This focus on cost reduction has led to a reduction of production employment as only management, marketing, research and design functions remain in Japan. The detachment between production and design could harm the longterm viability of this strategy. Innovation through continued quality improvements on the work floor has been a strength of Japanese firms, but with production moving overseas this process is interrupted.

${ }^{26}$ This is reflected in the 'Basic Law on SMEs' of 1999 arguing that small firms are "a source of diverse and vigorous growth" (METI, 2002b, p. I-0).

${ }^{27}$ The success of small high-tech firms in the United States has become an inspiration for Japan's troubled business community. There is hope that the 'Silicon Valley' model will lead to a revival of Japan's economy. Aspects of this 'model', such as venture financing and high-tech start-ups started to trickle into the Japanese business world and there has been a steady formalization of the venture capital market. Also, a series of policies inspired by American legislation has been implemented, including stimulation of collaboration between business and university, tax reforms to stimulate private investment in small firms and incubation centers and financing programs fostering start-up firms.
} 
cultural setting in Japan differs from other countries so that variations in unemployment can be less adequately explained using equation (1) and other influences may be taken into account. Both possibilities will be discussed in the next section. However, again we should stress that the estimated residuals are relatively small. For instance, estimated residuals for the United Kingdom and Spain are considerably larger. See Thurik (2003) and Thurik and Verheul (2003), respectively.

Using the results of equation (1) a prediction can be made of the level of unemployment in Japan in 2008. It is easy to calculate that $U_{t}-U_{t-L}$ equals 0.1 for $t=2008$ and $L=6$. This would imply that unemployment would hardly rise in a period of six years starting in 2000 and that unemployment would be about 5.5 percent in 2008. Clearly, this calculation depends upon the validity of equation (1) for Japan. Hence, it has to be interpreted with care because Japan is a relative outlier in that the model shows a minor underestimation of the rise in unemployment in Japan. Other factors that are not included in the model probably play a role. They will be discussed in the next section.

\section{Nature of business ownership in Japan}

We have shown that the Schumpeter effect of entrepreneurship (i.e., the degree to which entrepreneurship contributes to employment creation) is less strong in Japan than we would expect from our observations across OECD countries in the period between 1988 and 2000. Hence, it may be argued that small firms in Japan are somehow different. They may be less innovative or growing at a slower rate than firms in other countries, contributing less to employment creation. In the present section we present some rationale for this relatively low contribution of Japanese small firms to employment creation. We discuss characteristics of entrepreneurs, small firms and their environment and stress the importance of new venture creation and growth as well as innovation as means for bringing down unemployment.

New venture creation and growth in Japan is hampered by several factors. According to the SME White Paper 2002 (METI, 2002a) the most common problem for start-up firms is financial funding. For small firms banks are the main capital providers and the assessment criteria emphasize collateral requirement, credit guarantees to secure repayment and future cash flows. The current focus of banks on securing outstanding loans is likely to lead to a pre-selection of stable, low-risk investments. High-growth firms that have a large impact on employment are usually unable to meet collateral requirements, and, accordingly, are more likely to be turned down by banks.

The dependence on the banking system of Japanese small firms has led to severe financing obstacles. Because of the strong bundling of interests between keiretsu conglomerates and their banks, small firms were the first to become the victim in the recent financial sector crises. The deepening of the crisis in 1997 led to a severe credit crunch that particularly hit hard on small firms. The crisis in the financial sector caused the banks to be (even) more stringent in their loan assessments. Moreover, the financial health of banks depends on the survival of the larger keiretsu firms and protection of their interests in these firms will prevail over new investment in high-risk, high-growth firms.

Alternative sources of financial capital for small firms are limited. Subsidized loans programs initiated by the government amount up to eight percent of all small firm loans and also tend to focus upon low-risk, low-return investments. Moreover, the venture capital market in Japan is still underdeveloped. Only 0.7 percent of Japanese firms are funded with venture capital and Japan ranks lowest among all OECD countries in per capita venture capital investments (Reynolds et al., 2002). Venture capital is important for Japanese entrepreneurs to grow their firms. Firm growth of venture capital backed firms is in particular important because financiers want to cash in on their investments after a few years. Japanese financial markets have employed strict listing 
requirements in the past making hard for young firms to acquire capital. This may explain why Japanese venture firms take relatively long to go public on financial markets compared to their American counterparts (METI, 2000). The situation changed at the end of the 1990s when both the Osaka and Tokyo stock exchanges opened new markets and relaxed listing requirements opening up a range of financing options for small firms.

In addition to financial problems, start-up firms also encounter difficulties entering the market as newcomers because of the existing business channels between established firms (METI, 2002a). The importance of long-term close relationships, trust and reputation in Japan complicates the development of a dynamic business environment that is open to new entrants. Moreover, startup firms also have problems recruiting skilled personnel and acquire access to knowledge and business skills (METI, 2002a). Japanese employment practices such as lifetime employment, seniority wages and internal labor market mechanism, characteristic of the keiretsu structure, contribute to a low job mobility, particularly among mid-career employees. The rigidity of the employment system limits small firms' access to experienced employees. Small firms that want to expand are experiencing a shortage of skilled and experienced personnel even though unemployment is rising. Genda and Rebick (2000) show that during the 1990s vacancies have actually increased in periods of rising unemployment levels, suggesting a mismatch on the labor market $^{28}$.

Finally, innovativeness - which is generally considered to be a major determinant for the growth of (small) firms - in Japan is characteristic of large rather than of small firms. Of the total private $R \& D$ expenditures, only 7.2 percent takes place in firms with less than 500 employees, which is the lowest share of all OECD countries (OECD, 2002b). The relatively low R\&D investments in small firms also contribute to a low total factor productivity (TFP) growth. Urata and Kawai (2002) show that small firms on average exhibit lower growth of TFP than larger firms. However, Urata and Kawai (2002) stress that there is also diversity between small firms. For example, in the electrical machinery sector, small firms tend to outperform larger firms in terms of TFP growth. Small and medium sized firms traditionally have not been able to benefit from technology transfer from knowledge institutions. Knowledge transfer occurred largely through informal relationships between firms and university researchers, which typically benefited larger firms (Yoshihara and Tamai, 1999). In 1998 the Technology Transfer Law was enacted, leading to changes in the system of industry-business technology exchange. An important element is the establishment of Technology Licensing Organisations (TLOs) that manage the transfer of inventions and technology from universities to private firms. The TLOs are expected to create more transparency and create a more equal access to academic knowledge and technology. However, there is doubt whether the new system will actually improve small firm access to university research results (Kneller, 1999).

Firm growth is not only dependent upon the business and economic environment, but is also influenced by the entrepreneur's ambitions. A distinction can be made between 'shopkeeper' entrepreneurs, who earn a living through business ownership, and 'Schumpeterian' entrepreneurs, who strive after firm growth and innovation. It has been argued that entrepreneurs in Japan are motivated by 'idealistic' factors, such as the desire for independence and self-fulfillment (METI, 2002a). According to Reynolds et al. (2002) Japanese entrepreneurs start their businesses mainly because there are no employment alternatives. The high rate of 'necessity entrepreneurship' is an indication that the 'refugee' effect of unemployment plays an important role in Japan. Indeed,

\footnotetext{
${ }^{28}$ Mismatches in the labor market can be observed with respect to both age and industries. Small firms need welltrained and experienced personnel that have acquired specialized skills. The fact that unemployment is concentrated in the young and older age cohorts and that mid-career employees of large enterprises are still strongly attached to their employers, obstructs small firms' access to skilled personnel. In addition, personnel reductions have mainly occurred in manufacturing firms while growth of new firms during the 1990s has mainly taken place in the service and hightech sectors where other skills are required.
} 
Harada (2002) finds a positive relationship between the unemployment rate and the number of people who want to start their own business (i.e., aspiring entrepreneurs). Unemployment rates in Japan are relatively high for the younger and older people in Japan. Unemployment is relatively low and stable for middle-aged employees throughout the 1990s and only started to rise after 1997 $(\mathrm{OECD}, 2002 \mathrm{a})^{29}$. People between 25 and 40 years old are the most promising group of nascent entrepreneur as they have accumulated business skills and know-how ${ }^{30}$. Young unemployed who are pushed into self-employment generally have fewer skills as in Japan on-the-job training has always been an important source of skill formation. Older people tend not to desire firm growth and have less knowledge of modern technology and demand. It may be argued that firm growth is not a priority for Japanese entrepreneurs. Expansion may be further limited through a lack of business skills.

New venture creation and growth in Japan is further hampered by the social-cultural environment and attitudes of the people. Japan 'inherited' socio-cultural values, such as risk adversity and importance of group structures, from the keiretsu era. Yahagi and Isobe (2001) find that Japan ranks highest among a group of 21 (mostly OECD) countries with respect to the public perception of the risks involved in new venture creation. Also, the appreciation of entrepreneurial qualities in Japan ranks relatively low (as compared to other countries). Moreover, there is a strong emphasis on group loyalty in Japan. According to Hofstede $(1980,2001)$ 'individualism' leads to more entrepreneurial activity in a country, whereas 'collectivism' reduces a country's entrepreneurial spirit. Cultural inclinations such as risk adversity and collectivism are fairly constant over time (Hofstede, 2001, p. 34). Accordingly, it is a challenge for the Japanese government to create an entrepreneurial mindset in Japan.

Lastly, one should bear in mind that unemployment has always been very low in Japan, leading to a very tight labor market. In the 1980s small firms, in particular manufacturing firms, were confronted with a shortage of skilled personnel resulting in high labor costs (Genda and Rebick, 2000). Many small firms switched to labor saving techniques and automation of the production process. The limited contribution to employment creation by the small business sector during the 1980s should therefore be seen in the context of an overheated labor market.

\section{Discussion and conclusion}

We discussed the relationship between business ownership and unemployment in Japan. We have shown that the Schumpeter effect of business ownership on unemployment in Japan does hardly differ from that in other OECD countries. There is a minor tendency that our relationship underestimates the rise in unemployment. The transition of a managed to an entrepreneurial economy has contributed to a reduction in unemployment in several developed countries. In the entrepreneurial economy there is a revival of the Schumpeterian notion of the entrepreneur exploring new areas of economic growth at the heart of the economic process. At present there are few signs that the transition to the entrepreneurial economy has taken place in Japan. This is largely due to the very success of Japan's unique economic structure in the past. Until the 1970s Japan's economic structure reflected Schumpeter's vision in his later work in which he described innovation as being reduced to routine and in which bureaucratic and hierarchical organizations would be dominant (Schumpeter, 1944). Japanese firms however managed to combine hierarchical features with the flexibility of small firms in the keiretsu model, demonstrating that hierarchy and cooperation can be achieved through 'quasi' market or organizational relationships between firms. In short, Japan's lower propensity to shift from the managed to the entrepreneurial economy may

\footnotetext{
${ }^{29}$ For this age group job mobility is also relatively low.

${ }^{30}$ For further discussion of age effects on (decreasing) self-employment in Japan, we refer to Genda and Kambayashi (2002).
} 
account for the mild underestimation of the role of business ownership to bring down unemployment.

With the rise of a knowledge-driven economy, in Japan the need for a decentralized industrial structure where small and innovative firms play a major role has grown. The keiretsu model that proved superior in the exploitation of economies of scale and scope lost its competitive strength, and the keiretsu support for small firms evaporated without a true alternative industrial structure providing support to the small business sector. Perhaps what has facilitated the fast transition towards the entrepreneurial economy in some countries has been the existence of a solid market economy that could easily be geared to incorporate small firms.

The shift towards a more knowledge intensive economy involves entrepreneurial responses to changes in the economic environment in which old activities disappear as new economic activities are explored. This Schumpeterian dynamic takes two forms: on the one hand, small and new firms seek out new areas of economic value in new innovative industries. We showed that this mechanism has started to falter in Japan where few new start-ups are being established and where many obstacles remain for quick firm expansion. The second form involves the ability of existing small firms to revive established industries. Changes in technology have decreased the importance of scale economies in many industries and enable small firms to apply new technologies more quickly than larger firms. Also their ability to respond quickly to changes in demand adds to their ability to bring new life to existing sectors.

The future of Japan's economy and its industrial structure is the subject of intense debate. Some have called for a 'system' change in which Japan should emulate the experience of countries that successfully went through the transition. It has been suggested that industrial policy should serve as a catalyst in creating an institutional structure similar to that of Silicon Valley which could co-exist with the conventional manufacturing sector in which the keiretsu model still prevails (Yonekura, 1997). Others emphasize the potential of existing structures and favor augmentation of these structures to facilitate dynamism within the economy. For example, Cowling and Tomlinson (2002) stress the need to maintain the horizontal networks of small firms and enable small firms to become more independent from large firms. Both perspectives on industrial restructuring in Japan stress that entrepreneurship is the key to economic revival.

In this paper business ownership is used as a measure for entrepreneurship. However, the Schumpeterian view of entrepreneurship encompasses more than business ownership alone, and also includes innovative activity. Entrepreneurship also takes into account other types of business. During the 1990s large firms in Japan experimented with alternative, more dynamic forms of organization including corporate ventures, spin-off firms and configurations where large firms operate as financiers of new business ${ }^{31}$. In addition, there has been a large variety of new forms of cooperation and networks including new ventures, conventional small firms, former subcontractors, large keiretsu firms, academic research institutions, venture capital firms, banks and government organizations. From the 1990s onwards the industrial structure in Japan has undergone important changes, among which the weakening of the keiretsu structure. The experimentation with new business models has provided Japanese firms with alternative paths to increased competitiveness. Moreover, because of their struggle, the prestige of large firms eroded and gave way to the appreciation of entrepreneurial ventures. An entrepreneurial community has emerged presenting an alternative to the large firm bureaucracy.

The government has only played a minor role in bringing about these changes and has been slow to facilitate the transition towards the entrepreneurial economy. However, in 1999 the basic law on SMEs was amended fostering a more dynamic role for small firms. Moreover, inspired by American policies ${ }^{32}$, the Japanese government implemented several new laws aimed at facilitating

\footnotetext{
${ }^{31}$ These efforts have shown mixed performance results.

${ }^{32}$ Policies that had laid the foundations for the take-off of high-tech sectors in the United States in the 1980s.
} 
new venture creation, encouraging cooperation between universities and business and stimulating innovation in the small business sector. A distinction can be made between different policy objectives. On the one hand, policies in Japan are based on social considerations and aim at mitigating the harsh impact of the changed economic conditions in the short run. The massive injections of public funds in the financial sector, bankruptcy prevention measures and extensive public loan policies are aimed at preventing large-scale destruction of (employment in) the small business sector. On the other hand, policies in the long-term aim at fostering an entrepreneurial environment. With the lowest start-up rate of the OECD countries these policies have yet to prove their effectiveness.

Japan has a paradoxical history of both strong entrepreneurial dynamics and large firm dominance. The current breakdown of the symbiosis between large and small firms in Japan has led to a situation where small subcontracting firms have lost their protective environment and are faced with widespread destruction. On the other hand, a new environment - in which entrepreneurial firms flourish - has not yet emerged.

We will conclude on a positive note. Considering that Japan shows only a minor underestimation of the Schumpeter effect, there are good prospects for bringing down unemployment by stimulating business ownership. We identified several obstacles to growth of which some can be addressed through policy. Other obstacles are of an institutional and cultural nature and will be harder to change in the short run. The twin problems of unemployment and low growth confronting Japan can be countered if Japan manages to rekindle the old entrepreneurial dynamic by replacing the keiretsu structure with an institutional arrangement supporting small firms. Finally, we believe that Japan's unique system of inter-firm relations and low risk-taking is likely to result in a different approach to the challenges of the knowledge economy. Markets and non-hierarchical relations between firms are likely to be central elements of such a model. Industrial policy can facilitate the transition to an entrepreneurial economy by creating equal opportunities for small and large firms and promoting horizontal cooperation between firms.

\section{References}

Abe, M. and S. Ohta, 2001, Fluctuations in unemployment and industry labor markets, Journal of the Japanese and International Economies 15 (4), 437-464.

Aoki, M., 1990, Toward and economic model of the Japanese firm, Journal of Economic Literature, 18 (1), pp 1-27.

Audretsch, D.B., 1995, Innovation and Industry Evolution, Cambridge: MIT Press.

Audretsch, D.B., M.A. Carree and A.R. Thurik, 2001, Does entrepreneurship reduce unemployment? Tinbergen Institute discussion paper TI01-074/3, Erasmus University Rotterdam.

Audretsch, D.B. and A. R. Thurik, 2000, Capitalism and democracy in the $21^{\text {st }}$ century: from the managed to the entrepreneurial economy, Journal of Evolutionary Economics, 10, 17-34.

Audretsch, D.B. and A.R. Thurik, 2001, What is new about the new economy: sources of growth in the managed and entrepreneurial economies, Industrial and Corporate Change, 19, 795-821.

Audretsch, D.B. and A. R. Thurik, 2004, The model of the entrepreneurial economy, International Journal of Entrepreneurship and Education, forthcoming.

Audretsch, D.B., A.R. Thurik, I. Verheul and A.R.M. Wennekers (eds.), 2002, Entrepreneurship: Determinants and Policy in a European - US Comparison, Kluwer Academic Publishers.

Blau, D.M., 1987, A time series analysis of self-employment in the United States, Journal of Political Economy 95 (3), 445-467.

Carree, M.A., A.J. van Stel, A.R. Thurik and A.R.M. Wennekers, 2002, Economic development and business ownership: an analysis using data of 23 OECD countries in the period 1976-1996, Small Business Economics 19 (3), 271-290.

Carree, M.A. and A.R. Thurik, 2003, The impact of entrepreneurship on economic growth, in Handbook of Entrepreneurship Research, in: D.B. Audretsch and Z.J. Acs (eds), Boston/Dordrecht: Kluwer Academic Publishers, 437-471. 
Castells, M., 1996, The Information Age: Economy, Society and Culture, Volume I: The Rise of the Network Society, Cambridge MA/Oxford UK: Blackwell Publishers.

Castells, M., 1997, The Information Age: Economy, Society and Culture, Volume II: The Power of Identity, Malden MA/Oxford UK: Blackwell Publishers.

Castells, M., 1998, The Information Age: Economy, Society and Culture, Volume III: End of Millennium, Malden MA/Oxford UK: Blackwell Publishers.

Chuma, H., 2002a, Employment adjustments of Japanese firms during the current crisis, Industrial Relations 41 (4), 653-682.

Chuma, H., 2002b, Employment practices as social policy, WBI working paper, Washington: The World Bank.

Cowling, K. and P.R. Tomlinson, 2001, The problem of regional "hollowing out" in Japan: Lessons for regional industrial policy, Warwick Economic Research Papers No 625, University of Warwick.

Cowling, K and P.R. Tomlinson, 2002, Re-visiting the roots of Japan's structural decline: the role of the Japanese corporation, International Review of Applied Economics, 16(4), 373-390.

Dore, R., 1986, Flexible Rigidities: Industrial policy and structural adjustment in the Japanese economy 1970-1980, London: The Athlone Press.

EIM, 2003, Compendia 2000.2: a dataset of business ownership rates in 23 OECD countries, forthcoming.

Gartner, W.B. and S.A. Shane, 1995, Measuring entrepreneurship over time, Journal of Business Venturing $10(4), 283-301$.

Gerlach, M.L., and J.R. Lincoln, 2000, Economic organization and innovation in Japan: Networks, spinoffs and the creation of enterprise, in: Von Krogh, G., Nonaka, I. and T. Nishiguchi (eds.), Knowledge Creation: a Source of Value, London: Macmillan Press Ltd, 151-198.

Genda, Y., 1998, Job creation and destruction in Japan, 1991-1995, Journal of the Japanese and International Economies 12 (1), 1-23.

Genda, Y. and M.E. Rebick, 2000, Japanese labour in the 1990s: stability and stagnation, Oxford Review of Economic Policy, 16 (2), pp. 85-102.

Genda, Y. and R. Kambayashi, 2002, Declining self-employment in Japan, Journal of the Japanese and International Economies 16 (1), 73-91.

Geroski, P.A., 1995, What do we know about entry?, International Journal of Industrial Organization, 13, 421-440.

Glisby, M. and N. Holden, 2003, Contextual constraints in knowledge management theory: the cultural embeddedness of Nonaka's knowledge-creating company, Knowledge and Process Management 10 (1), 29-36.

Granger, C.W.J., 1969, Investigating causal relations by econometric models and cross-spectral methods, Econometrica, 37, 424-438.

Harada, N., 2002, Potential entrepreneurship in Japan, JCER Discussion Paper No. 81, Tokyo: Japan Center for Economic Research.

Henriquez, C.M., I. Verheul, I. van der Geest and C. Bischoff, 2002, Determinants of entrepreneurship in France, in: D.B. Audretsch, A.R. Thurik, I. Verheul and A.R.M. Wennekers (eds.), Entrepreneurship: Determinants and Policy in a European - US Comparison, Kluwer Academic Publishers, 83-120.

Hirschmeier, J., 1964, The Origins of Entrepreneurship in Meiji Japan, Cambridge, MA: Harvard University Press.

Hofstede, G., 2001, Culture's Consequences $2^{\text {nd }}$ edition, Thousand Oaks: Sage Publications.

Hofstede, G., 1980, Culture's Consequences: International Differences in Work-Related Values, Beverley Hills: Sage.

Ikeda, M., 1998, Globalisation's impact upon the subcontracting system, in: Hasegawa, H. and G.D. Hook (eds.), Japanese Business Management: Restructuring for Low Growth and Globalization, London: Routledge, 109-127.

Imai, K., 1980, Japan's industrial organization, in: Sato, K. (eds.), Industry and Business in Japan, New York: M.E. Sharp Inc., 74-135.

Imai, K. and H. Itami, 1984, Interpenetration of organization and market: Japan's firm and market in comparison with the U.S., International Journal of Institutional Economics, 2(4), 285-310.

Inoue, H., 2000, Companies Continue to Unwind Cross-Shareholdings: The Fiscal 1999 CrossShareholding Survey, Research Report, Tokyo: NLI Research Institute.

Kameyama, N., 2001, Japan's experience with employment policy, in: Betcherman, G. and R. Islam (eds.) East Asian Labor Markets and the Economic Crisis, World Bank, 467-492. 
Kato, T., 2001, The end of lifetime employment in Japan?: Evidence from national surveys and field research, Journal of the Japanese and International Economies 15 (4), 489-514.

Katz, J.P., Krumwiede, D.W. and M.W. de Czege, 1998, Total quality management in the global marketplace: the impact of national culture on TQM implementation, International Journal of Management 15 (3), 349-356.

Kawai, H. and S. Urata, 2002, Entry of small and medium enterprises and economic dynamism in Japan, Small Business Economics 18 (1), 41-51.

Kneller, R., 1999, Intellectual property rights and university-industry technology transfer in Japan, Science and Public Policy 26(2), 113-124.

Kwoka, J.E. and L.J. White, 2001, The new industrial organization and small business, Small Business Economics 16 (1), 21-30.

Larimer, T., 2003, Japan, Nissan and the Ghosn revolution, The Chazen Web Journal of International Business, Spring 2003, New York: Columbia Business School.

Lincoln, J.R., Gerlach, M. and C. Ahmadjian, 1998, Evolving patterns of keiretsu organization and action in Japan, Research in Organizational Behavior 20, 303-345.

METI, 2000, White Paper on Small \& Medium Size Enterprises 2000, Tokyo: Small and Medium Enterprise Agency / METI.

METI, 2002a, White Paper on Small \& Medium Size Enterprises 2002, Tokyo: Small and Medium Enterprise Agency / METI.

METI, 2002b, Outline of Japan's SME Policies January 2002, Tokyo: Small and Medium Enterprise Agency / METI.

METI, 2003, White Paper on Small Medium Enterprises 2003, Tokyo: Small and Medium Enterprise Agency / METI.

Miyajima, H., 1994, The transformation of Zaibatsu to postwar corporate groups - from hierarchically integrated groups to horizontally integrated groups, Journal of the Japanese and International Economies 8 (3), 293-328.

Nakamura, H., Akiya, S., Kiyonari, T, Yamazaki, M. and T. Bando, 1981, Gendai chusho kigyo shi (History of modern SMEs), Tokyo: Nihon Keizai Shimbunsha.

Nakamura, M., Vertinsky, I. and C. Zietsma, 1997, Does culture matter in inter-firm cooperation? Research consortia in Japan and the U.S.A., Managerial and Decision Economics 18, 153-175.

OECD, 2002a, Labor Force Statistics 2002, Paris: OECD.

OECD, 2002b, OECD Small and Medium Enterprise Outlook 2002, Paris: OECD.

Porter, M.E., Takeuchi, H. and M. Sakakibara, 2000, Can Japan Compete?, Houndmills: MacMillan Press.

Reynolds, P.D., S.M. Camp, B.D. Bygrave, E. Autio and M. Hay, 2002, Global Entrepreneurship Monitor 2001, London: London Business School and Babson College.

Schumpeter, J., 1944, Capitalism, Socialism and Democracy, London: Henderson and Spalding Ltd.

Thurik, A.R., 2003, Entrepreneurship and unemployment in the UK, Scottish Journal of Political Economy, 50 (2), 264-290.

Thurik, A.R. and I. Verheul, 2003, The relationship between entrepreneurship and unemployment: the case of Spain, in: D. Urbano etc (eds), Entrepreneurship (Creación de Empresas), Barcelona: Servei de Publicacions de la UAB, 521-547.

Urata S. and H. Kawai, 2002, Technological progress by small and medium enterprises in Japan, Small Business Economics 18 (1), 53-67.

Van Stel, A.J., 2003, COMPENDIA 2000.2: a harmonized data set of business ownership rates in 23 OECD countries, EIM Research Report H200302, Zoetermeer: EIM Business and Policy Research.

Wennekers, A.R.M. and A.R. Thurik, 1999, Linking entrepreneurship and economic growth, Small Business Economics, 13 (1), 27-55.

Wennekers, A.R.M. and A.R. Thurik, 2001, Institutions, entrepreneurship and economic performance, in: A. Lundström and L. Stevenson (eds.), Entrepreneurship Policy for the Future, Swedish Foundation for Small Business Research, 2001, 51-87.

Wennekers, A.R.M., A.R. Thurik, N.G. Noorderhaven and G. Hofstede, 2002, Cultural and economic determinants of business ownership across countries, in: W.D. Bygrave etc (eds), Frontiers of Entrepreneurship Research 2001, Center for Entrepreneurial Studies, Babson College, MA, 179-190.

White, L.J., 1982, The determinants of the relative importance of small business, Review of Economics and Statistics 64, 42-49.

Whittaker, H., 1997, Small Firms in the Japanese Economy, Cambridge: Cambridge University Press. 
Whittaker, H., 2001, Crisis and Innovation in Japan: A new future through techno-entrepreneurship, ESRC Centre for Business Research Working Paper No 193, Cambridge University.

Williamson, O.E., 1975, Markets and Hierarchies: Analysis and antitrust implications, New York: The Free Press.

Yahagi, T. and T. Isobe, 2001, Venture business no ikusei to kokka keizai (Cultivation of venture business and the national economy), Venture Forum, No. 178, Venture Enterprise Center, Japan.

Yonekura, S., 1997, From keiretsu model to Silicon Valley model: Why is Japanese business troubled? A historical insight, Institute of Innovation Research Working Paper, Tokyo: Hitotsubashi University.

Yoshihara, M. and K. Tamai, 1999, Lack of incentive and persisting constraints: factors hindering technology transfer at Japanese universities, in: Branscomb, L.M., Kodama, F. and R. Florida (eds.), Industrializing Knowledge: University-Industry Linkage in Japan and the United States, Cambridge MA: MIT Press, 348-364. 